\title{
Sundial for Time-keeping in Jaisalmer Fort
}

\author{
Aalok Pandya*, Tej Bahadur** and Sandip Bhattacharya***
}

(Received 25 July 2016; 12 December 2016)

\begin{abstract}
The paper reports the study of a special Sundial installed in the Jaisalmer fort in 1861 CE. It reveals that the graduation is based on the traditional Indian system of time-keeping. The divisions represent equal time intervals of 24 minutes corresponding to one ghati. An attempt has been made to estimate the accuracy of the dial readings through our own observations.
\end{abstract}

Key words: Accuracy of Sundial, Indian system of time keeping, Sundials.

\section{INTRODUCTION}

Time-keeping has been very significant in the scientific as well as socio-cultural traditions around the world. There is no human invention more ancient or more interesting, than that of Sundial; so ancient that the exquisite essayist, Charles Lamb says,

"Adam could scarce have missed it in Paradise; and so interesting, that we may be sure that man's first want, after supplying craving of hunger, would be to invent some instrument by which he could measure the day-time into proportions (Alfred Gatty, 1872)."

In the significant contributions such as Alfred Gatty in her book Sundials has elaborated this fact at length.

Stone observatories have played an important role in the development and evolution of Astronomy (Sharma, 1991, 2008, Shylaja, 2011). Prahlad Singh in his book, Indian and Islamic
Stone Observatories (Singh, 2009) and Kochar and Narlikar $(1993 ; 1994)$ have documented the heritage of stone observatories and variety of timekeeping instruments in a comprehensive manner. And yet, there are a few historical intellectual contributions that have not caught the eyes of the scholarly world.

Herodotus (443 BCE) said, "It was from the Babylonians that the Greeks learned concerning the pole, the gnomon, and the twelve parts of the day (Kaye, 1973)." Since the ancient Greek experimentations, around the world, it has been a tradition of dividing a day into twelve parts. But, in ancient India it was not strictly so. In one of the ancient Indian traditions, the day is divided into 30 parts as well (Bose, 1971). The Sundial in Jaisalmer fort is based on one of these Indian traditions. The Sundial is located on the roof top of the Raj Mahal Palace Museum in the Jaisalmer fort founded by Rajput ruler Rawal Jaisal in the year 1156 CE (Tod, 1828).

\footnotetext{
* JECRC University, Jaipur 303905 India; Email: aalok.pandya@jecrcu.edu.in; and aalok@uniraj.ernet.in

** Manipal University, Jaipur 303007 India;

***B. M. Birla Planetarium, Statue Circle, Jaipur 302001 India; and *Astronomy and Astrophysics Resource Development and Research Academy (AARDRA), Jaipur.
} 


\section{The Sundial in Jaisalmer Fort}

The Sundial is carved on a yellow limestone slab which is abundant in Jaisalmer. The dial is mounted on a platform in the South-West corner of the roof top of Raj Mahal palace museum in the Jaisalmer fort (Fig. 1).

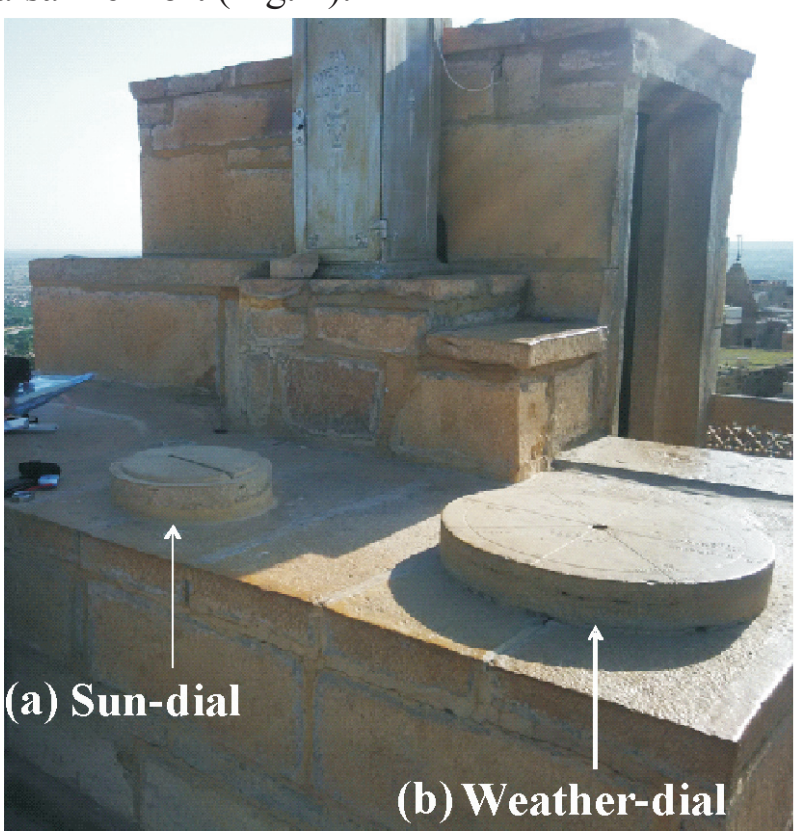

Fig. 1: (a) Sundial in Jaisalmer fort with a straight groove for attaching a triangular gnomon; and (b) Weather-dial with a hole at the centre for a flag post.

The inscription on the Sundial (Fig. 2) is in Devnagari script as follows:

महाराजाधिराज राज राजेसर महारवलजी श्रीश्री १०८ श्री राणजीत सिंह जी बहादुर जंतर लगा करायो हसंते गजधर सरूपजी खमाणी सं. १९९६ २ मिती मागसरस ६१

An appropriate English translation of this could be given as:

At the behest of Maharjadhiraj Raj Rajeshwar Maharawalji Shree Shree 108 Shree Ranjit Singhji Bahadur, this instrument was installed by Gajdhar Saroopji Khemani on 2nd day of the Margshirsh month of Samvat 1916, 1861 CE.

Thus, according to the inscription on it (Fig. 2), the Sundial was created on $2^{\text {nd }}$ day of the second half of Mārgśirșa Month of Samvat 1916 that upon conversion implies $26^{\text {th }}$ November, 1861 $\mathrm{CE}$, and that it was created under the instructions of the ruler Mr. Ranjeet Singh (1846-1864 CE). There used to be an observer around the dial who after regular interval used to ring a giant bell, apprised Dr. Raghuveer Singh the Superintendent of the Raj Mahal Palace Museum.

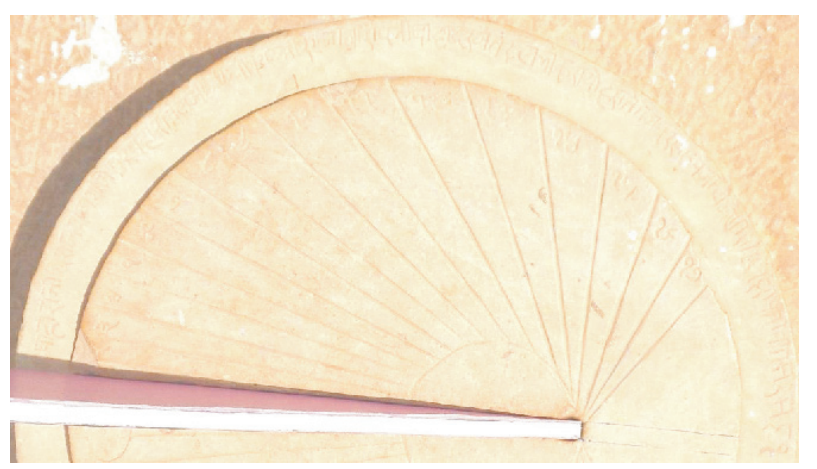

Fig. 2: Close up view of the Sundial.

The erstwhile princely state Jaisalmer is known to have a separate calendar Bhattik Samvat, which is well mapped with the Vikram Samvat except for the fact that the first month of Bhattik Samvat is Mārgśirșa and not Caitra (Rajasthan District Gazetteers- Jaisalmer, 1973; and Dasharath Sharma, 1966). However, Vikram Samvat and the Gregorian calendar were in fashion in the medieval period also, but, Mārgśirșa month was still considered for the new-year celebrations and other auspicious occasions. Thus, the inscribed day of the Märgśirṣa month corresponds to $26^{\text {th }}$ November, $1861 \mathrm{CE}$.

The Sundial was used for some time and later it was dumped in the store of the palace. It was rediscovered in 1993 CE by Dr. Raghuveer Singh (Raj Mahal palace Museum, Jaisalmer) when he took over as the Superintendent of the palace and he got it reinstalled on the roof top of the palace. Close to the Sundial, there is another interesting instrument called Weather-dial (Fig. 1 (b)) which is discussed later in the section- 4 of the present paper. 


\section{Observation and Analysis}

In order to check the functioning of the Sundial, we installed a makeshift triangular gnomon $N-27^{\circ}$ direction exactly fitting the groove on the dial as shown in Fig. 3. The time derived by observing the shadow of the gnomon on the horizontal dial matched fairly well with Indian Standard Time (IST) with all necessary calibrations due to longitude difference and the equation of time for the date. The physical measurements are as follows:

\section{The position of Sundial as per GPS readings:}

$N-26^{\circ} 54^{\prime} 46.14^{\prime \prime} ; E-70^{\circ} 54^{\prime} 48.36^{\prime \prime}$; and altitude: 253.4 meters.

Diameter of the Sundial: $36.5 \mathrm{~cm}$.

This is based on system of time-keeping in Indian calendar (Bose, et al. 1971). This could be understood as follows:

\section{4 minutes $=1$ ghati \\ $2 \frac{1}{2}$ ghati $=1$ hour;}

30 ghati is $=12$ hours; and 12 hours $=4$ praharas.

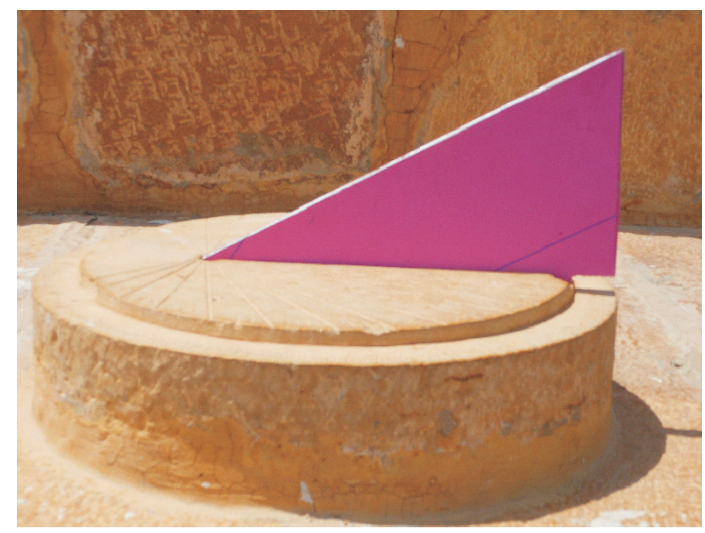

Fig. 3: Sundial with a makeshift triangular gnomon with inclination $N-27^{\circ}$. (Angle $\sim N-27^{\circ}$ is the latitude of Jaisalmer)

We observed that the makeshift gnomon did not cast any shadow on the dial at the time of meridian that is local noon on $13^{\text {th }}$ September, 2015 as depicted in Fig. 4 (a). Moreover, we recorded observations and further investigated on $9^{\text {th }}$ May, and $25^{\text {th }}$ and $26^{\text {th }}$ June, 2016. Observations on June $25^{\text {th }}$ and $26^{\text {th }}$ are important as they were close to $21^{\text {st }}$ June the summer solstice.

There is difference of $11.58^{\circ}$ between the longitudes of Jaisalmer and IST $\left(82.58^{\circ}\right)$. The local time of Jaisalmer differs from IST by $11.58 \times 4=46.34$ minutes. Further, there ought to be correction of 3.6 minutes on $9^{\text {th }}$ May, and -2.4 minutes on $25^{\text {th }}$ and $26^{\text {th }}$ June as per the equation of time. The local noon was observed on $9^{\text {th }}$ May at $\sim 12: 49 \mathrm{Hr}$ IST, and on $25^{\text {th }}$ and $26^{\text {th }}$ June at $\sim 12: 44 \mathrm{Hr}$ IST on $13^{\text {th }}$ September, 2015.

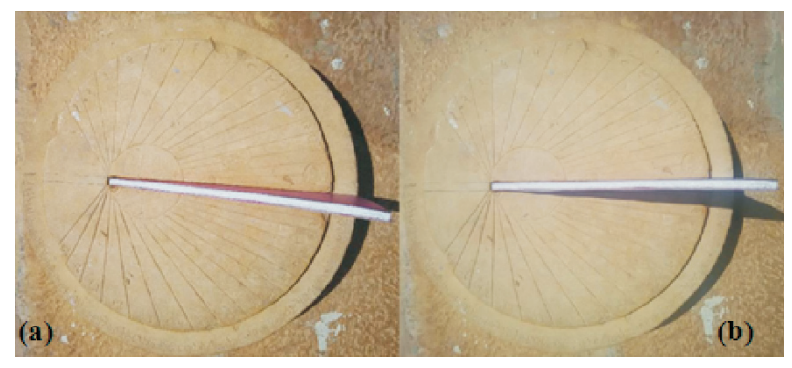

Fig. 4: The Observations on the Sundial on $13^{\text {th }}$ September, 2015 with makeshift triangular gnomon: (a) At local noon with no shadow; and (b) 48 minutes (2 ghatis) post meridian.

As the Sun rises from the North of equator, we observe shadow (Fig. 5 a) of the gnomon even before the East-West line as expected.

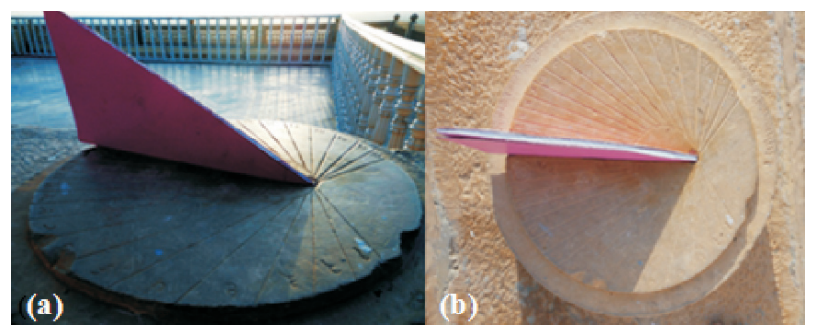

Fig. 5: (a) Observation at Sun rise on $9^{\text {th }}$ May, 2016 (6:28 AM): The shadow is below the East-West line; and

(b) Observation just after the Sun rise on $9^{\text {th }}$ May, 2016 (7:28 AM).

We recorded observations on the Sundial on $9^{\text {th }}$ May, $25^{\text {th }}$ and $26^{\text {th }}$ June, 2016. The observations are as follows: 
Table 1: Observations on $25^{\text {th }}$ and $26^{\text {th }}$ June, 2016.

\begin{tabular}{|c|c|c|c|c|}
\hline & & \multicolumn{3}{|c|}{ Time (IST) } \\
\hline S. No. & Graduation & $9^{\text {th }}$ May, 2016 & $25^{\text {th }}$ June, 2016 & $26^{\text {th }}$ June, 2016 \\
\hline 1 & 1 & $\begin{array}{c}\text { Sun Rise: 06:02 AM } \\
\text { (Not recordable) }\end{array}$ & Not recorded & $\begin{array}{c}\text { Sun Rise: 05:54 AM } \\
\text { (Not recordable) }\end{array}$ \\
\hline 2 & 2 & Not recordable & Not recorded & Not recordable \\
\hline 3 & 3 & 06:16 AM & & 06:22 AM \\
\hline 4 & 4 & 06:40 AM & & 06:46 AM \\
\hline 5 & 5 & 07:04 AM & & 07:10 AM \\
\hline 6 & 6 & 07:28 AM & & 07:34 AM \\
\hline 7 & 7 & 07:52 AM & & 07:58 AM \\
\hline 8 & 8 & 08:16 AM & & 08:22 AM \\
\hline 9 & 9 & 08:40 AM & & 08:46 AM \\
\hline 10 & 10 & 09:04 AM & & 09:10 AM \\
\hline 11 & 11 & 09:28 AM & & 09:34 AM \\
\hline 12 & 12 & 09:52 AM & & 09:58 AM \\
\hline 13 & 13 & 10:16 AM & & 10:22 AM \\
\hline 14 & 14 & 10:40 AM & & 10:46 AM \\
\hline 15 & 15 & Not recordable & Not recordable & Not recordable \\
\hline 16 & 16 & Not recorded & Not recorded & Not recorded \\
\hline 17 & 17 & Not recorded & Not recorded & Not recorded \\
\hline 18 & 18 & 12:16 PM & *12:22 PM & 12:22 PM \\
\hline 19 & Zenith & 12:40 PM & 12:44 PM & 12:44 PM \\
\hline 20 & Zenith & 12: $50 \mathrm{PM}$ & 12:52 PM & 12:52 PM \\
\hline 21 & 1 & 12:58 P M & 01:08 PM & 01:08 PM \\
\hline 22 & 2 & & 01:32 PM & \\
\hline
\end{tabular}

Table 2: Observations on $9^{\text {th }}$ May and $26^{\text {th }}$ June, 2016 and their respective Shadow Angles

\begin{tabular}{|c|c|c|c|}
\hline Graduation & \multirow{2}{*}{$\begin{array}{c}\text { Observed Shadow Angle } \\
h\end{array}$} & \multicolumn{2}{|c|}{ Time (IST) } \\
\cline { 3 - 4 } & (From the North-South Line) & 9 th May, 2016 & 26th June, 2016 \\
\cline { 3 - 4 } & & & $12: 44 \mathrm{PM}$ \\
\hline Zenith & $0^{\circ}$ & $12: 40$ PM & $12: 22 \mathrm{PM}$ \\
\hline $\mathbf{1 8}$ & $3^{\circ}$ & $12: 16 \mathrm{PM}$ & \\
\hline
\end{tabular}

* The observations on $25^{\text {th }}$ June were recorded only after 12:22 PM. Observations on $9^{\text {th }}$ May and $26^{\text {th }}$ June could be tabled with respect to Hour angle $\mathrm{H}=0^{\circ}$ as: 


\begin{tabular}{|c|c|c|c|}
\hline $\mathbf{1 7}$ & $6^{\mathrm{O}}$ & Not recorded & Not recorded \\
\hline $\mathbf{1 6}$ & $9^{\circ}$ & Not recorded & Not recorded \\
\hline $\mathbf{1 5}$ & Missing Graduation & Not recordable & Not recordable \\
\hline $\mathbf{1 4}$ & $13.5^{\circ}$ & $10: 40$ AM & $10: 46$ AM \\
\hline $\mathbf{1 3}$ & $18^{\circ}$ & $10: 16$ AM & $10: 22$ AM \\
\hline $\mathbf{1 2}$ & $22^{\circ}$ & $09: 52$ AM & $09: 58$ AM \\
\hline $\mathbf{1 1}$ & $28^{\circ}$ & $09: 28$ AM & $09: 34$ AM \\
\hline $\mathbf{1 0}$ & $33.5^{\circ}$ & $09: 04$ AM & $09: 10$ AM \\
\hline $\mathbf{9}$ & $39.5^{\circ}$ & $08: 40$ AM & $08: 46$ AM \\
\hline $\mathbf{8}$ & $47^{\circ}$ & $08: 16$ AM & $08: 22$ AM \\
\hline $\mathbf{7}$ & $56^{\circ}$ & $07: 52$ AM & $07: 58$ AM \\
\hline $\mathbf{6}$ & $66.5^{\circ}$ & $07: 28$ AM & $07: 34$ AM \\
\hline $\mathbf{5}$ & $77.5^{\circ}$ & $07: 04$ AM & $07: 10$ AM \\
\hline $\mathbf{4}$ & $90^{\circ}$ & $06: 40$ AM & $06: 46$ AM \\
\hline $\mathbf{3}$ & $102.50^{\circ}$ & $06: 16$ AM & $06: 22$ AM \\
\hline $\mathbf{2}$ & $113.50^{\circ}$ & Not recordable & Not recordable \\
\hline $\mathbf{1}$ & $12.4 .00^{\circ}$ & Sun Rise & Sun Rise \\
& & $06: 02$ AM & $05: 54$ AM \\
\hline & & Not recordable $)$ & (Not recordable) \\
\hline
\end{tabular}

It is noticeable that the time difference between consecutive readings is 24 minutes. To cross-check that this is exactly the intended design, we compared the angles for every 24 minutes from Noon with calculated values using the formula. We now calculate the theoretical values of shadow angle using the formula:

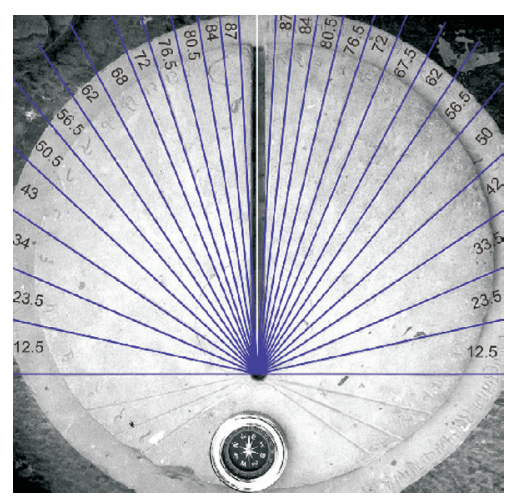

$$
\tan h=\sin (\Phi) * \tan [H]
$$

(1) Where, $h$ is the shadow angle, $\Phi=27^{\circ}$ (latitude angle) and $H$ is the hour angle.

We now estimate the error between the observed and theoretical value of shadow angles $h$ and $h^{\prime}$ with time and plot their variation with time.

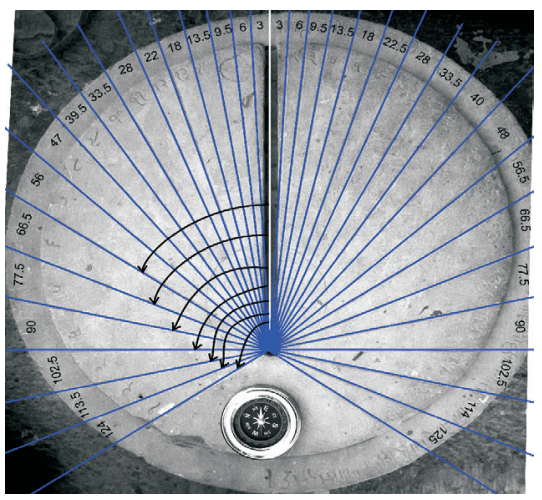

Fig. 6: The shadow angles: (a) As measured about the East-West line from the foot of the gnomon;

(b) Measured from the meridian line. 
Fig. 6 (a) and 6 (b) represent the scheme of angular division or graduations drawn on the Sundial. Computer graphics were used to simulate the lines superimposed on a photograph of the dial taken carefully from a point just vertically above the center of the dial.
We now summarize all our observations measured in time and corresponding shadow angles and estimate the error between the observed shadow angles and their theoretical values.

Table 3: Variation in Observed and Theoretical Values of Shadow Angles $h$ and $h^{\prime}$ with Time

\begin{tabular}{|c|c|c|c|c|c|}
\hline \multirow[t]{2}{*}{ Graduation } & \multirow[t]{2}{*}{$\begin{array}{c}\text { IST } \\
\left(26^{\text {th }} \text { June }\right)\end{array}$} & \multirow{2}{*}{$\begin{array}{r}\text { Time Interval } \\
\text { (From Zenith) } \\
\Delta t \text { (Minutes) }\end{array}$} & \multicolumn{2}{|c|}{$\begin{array}{l}\text { Shadow Angle } \\
\text { From the North-South Line } \\
\text { (At the foot of the gnomon) }\end{array}$} & \multirow{2}{*}{$\begin{array}{l}\text { Error } \\
\left(h-h^{\prime}\right)\end{array}$} \\
\hline & & & $\begin{array}{c}\text { Observed } \\
\text { value } h\end{array}$ & $\begin{array}{c}\text { Theoretical } \\
\text { Value h' }\end{array}$ & \\
\hline 19 & 12:44 PM & 0 & $0^{\mathrm{O}}$ & $0^{\mathrm{O}}$ & $0.0^{\mathrm{O}}$ \\
\hline 18 & $12: 22 \mathrm{PM}$ & 24 & $3^{\mathrm{O}}$ & $2.72^{\circ}$ & $0.28^{\circ}$ \\
\hline 17 & Not recorded & Not recorded & $6^{\circ}$ & $5.49^{\circ}$ & $0.51^{\mathrm{O}}$ \\
\hline 16 & Not recorded & Not Recorded & $9.5^{\circ}$ & $8.36^{\mathrm{O}}$ & $1.14^{\mathrm{O}}$ \\
\hline 15 & $\begin{array}{c}\text { Not record- } \\
\text { able }\end{array}$ & Not recorded & $\begin{array}{c}\text { Missing } \\
\text { Graduation }\end{array}$ & $11.39^{\circ}$ & - \\
\hline 14 & 10:46 AM & 120 & $13.5^{\circ}$ & $14.64^{\circ}$ & $-1.14^{\mathrm{O}}$ \\
\hline 13 & $10: 22 \mathrm{AM}$ & 144 & $18^{\circ}$ & $18.20^{\circ}$ & $-0.20^{\circ}$ \\
\hline 12 & 09:58 AM & 168 & $22^{\mathrm{O}}$ & $22.17^{\circ}$ & $-.17^{\circ}$ \\
\hline 11 & 09:34 AM & 192 & $28^{\circ}$ & $26.69^{\circ}$ & $1.31^{\mathrm{O}}$ \\
\hline 10 & 09:10 AM & 216 & $33.5^{\circ}$ & $31.92^{\mathrm{O}}$ & $1.58^{\circ}$ \\
\hline 9 & 08:46 AM & 240 & $39.5^{\circ}$ & $38.09^{\circ}$ & $1.41^{\mathrm{O}}$ \\
\hline 8 & 08:22 AM & 264 & $47^{\circ}$ & $45.47^{\circ}$ & $1.53^{\circ}$ \\
\hline 7 & 07:58 AM & 288 & $56^{\mathrm{O}}$ & $54.33^{\circ}$ & $1.67^{\mathrm{O}}$ \\
\hline 6 & 07:34 AM & 312 & $66.5^{\circ}$ & $64.84^{\mathrm{O}}$ & $1.66^{\mathrm{O}}$ \\
\hline 5 & 07:10 AM & 336 & $77.5^{\circ}$ & $76.92^{\mathrm{O}}$ & $.58^{\mathrm{O}}$ \\
\hline 4 & 06:46 AM & 360 & $90^{\circ}$ & $90^{\circ}$ & $0.0^{\mathrm{O}}$ \\
\hline $3 *$ & 06:22 AM & 384 & $102.50^{\mathrm{O}}$ & $103.07^{\mathrm{O}}$ & $-0.57^{\mathrm{O}}$ \\
\hline $2 *$ & 05:58 AM** $^{* *}$ & 408 & $113.50^{\circ}$ & $115.09^{\circ}$ & $-1.59^{\circ}$ \\
\hline $1 *$ & 05:34 $\mathrm{AM}^{* *}$ & 432 & $124.00^{\circ}$ & $125.61^{\mathrm{O}}$ & $-1.61^{\mathrm{O}}$ \\
\hline
\end{tabular}

*Graduations 1, 2 and 3 are below the East-West line.

**These observations (time and images) were not recorded. 


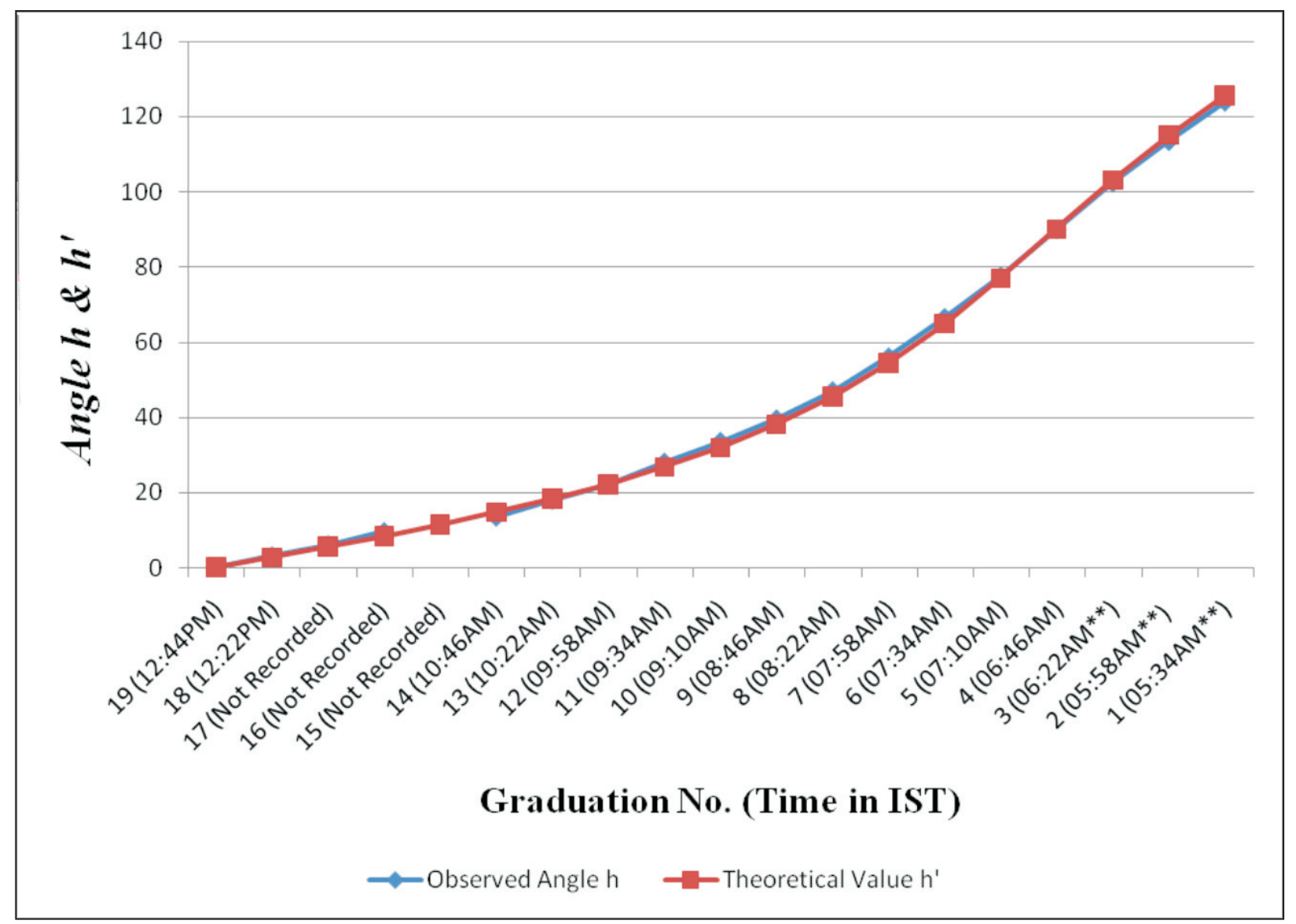

Fig. 7: Curve representing the error between the observed and theoretical value of shadow angle $h$ and $h^{\prime}$ with time.

We notice that there is reasonable overlap of the two curves representing shadow angles $h$ and $h^{\prime}$. The total time interval recorded for passage of the shadow across 16 graduations is 384 minutes. This proves the point that the graduations were intended for a time difference of 24 minutes as per the Hindu time reckoning system.

Observations as well as theoretical calculations reveal that one graduation corresponding to shadow angle $78.70^{\circ}$ from the East-West line that is $11.30^{\circ}$ from the meridian line is missing on the dial. This is found on both the sides of North-South line.

\section{Weather Dial}

The weather dial in Jaisalmer fort is an interesting instrument (see Fig. 8). To understand the functioning of the weather dial, we need an extensive scientific study based on observations for several years. However, the basic information known about the weather dial indicates that it works on the wind-pattern and the direction of the wind plays an important role in the rainfall.

Aflag post used to be mounted at the central hole of the dial to indicate the wind direction. It is said that observations of the wind directions were recorded on Akhātīj (Akșaya Tritīyā), a particular day in Indian calendar which generally occurs in late April or May. And wind pattern in turn can tell us about the possible rainfall.

In Jaisalmer region cold winds blow from West to East in the winters. Based on experience, there is belief that the wind pattern in Jaisalmer 
changes around Akhātīj (Akșaya Tritīya). This seems to be in reasonable agreement with modern weather science (Forecasting manual, IMD; Das, et. al, 2002). In winters winds blow from northwestern high pressure zone to the low air pressure zones. This pattern changes around early summer. With the apparent northward movement of the Sun towards the Tropic of Cancer in late March, temperature rises in North India. April, May and June are the months of summer in North India. The differential heating of land and sea is believed to be the primary cause of the monsoon by meteorologists. Low pressure at Inter Tropical Convergence Zone (ITCZ) which is located over North India in month of May becomes so intense that it pulls the trade winds of the southern hemisphere northwards. The wind pattern thus turns south-westerly in western Rajasthan in early May (Forecasting Manual, IMD. 1972; Das, et. al, 2002). This is prominent cause of the monsoon.

A similar tradition of rainfall forecasting is observed in Jantar-Mantar observatory at Jaipur also (Singh, 2009; Ibid 58-60). This is a tradition continued for about three hundred years since the times of Maharaja Jai Singh. In Jaipur observatory the observations for rainfall are made on the day of 'Guru Pūrnima' that is full moon day of Asādha month of Indian calendar which occurs on some day in July.

Since, weather forecasting is based on statistical analysis, these observations should continue throughout the season. Thus, in some sense, observations on Aksaya Tritiya could be meant for early or advance forecasting of monsoon. And as the weather forecasting is dependent on repetitive observations and statistical analysis, an extensive scientific study based on observations for couple of years is suggested.

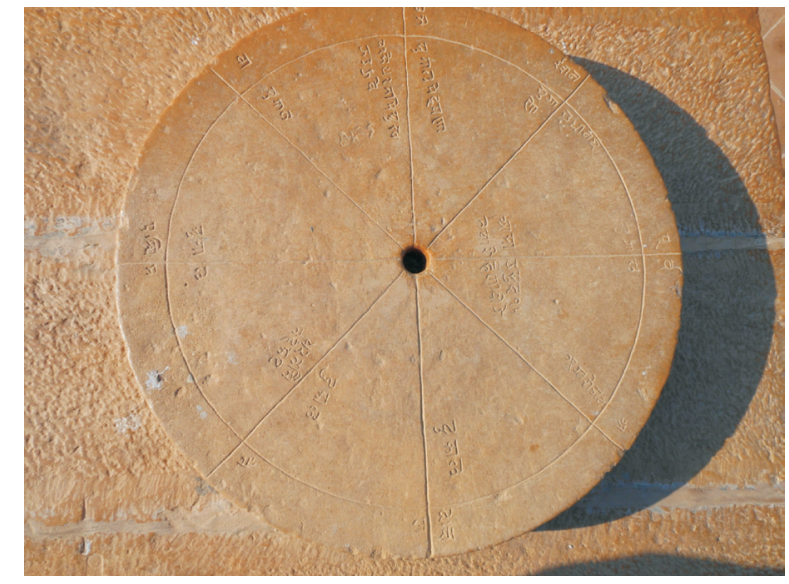

Fig. 8: Weather-dial with a central hole at the centre for a flag post.

\section{Discussion}

It is interesting to note that different geographical regions and different cultures have different means and methods of time-keeping. The Sun-dial in the Jaisalmer fort was a functional time-keeping instrument with a fair degree of accuracy.

It is interesting to note that the dial was designed to read intervals of 24 minutes as needed by the local calendar makers. The dial is usable even today by placing a gnomon. However, there are errors, as mentioned in the table which are because (i) the dial was not installed properly aligning its axis in the N-S direction; and (ii) The location is not suited for afternoon and evening observations. If it is relocated to a better location with exact N-S alignment, it will become an 'active' Sundial reading ghatis. The extra lines to the South of E-W line may not be of relevance now; but its use for any other purpose needs to be explored.

However, the Sundial while it was reinstalled was not exactly placed in the NorthSouth direction. There is an error of about $4^{\circ}$ with the North-South direction as shown in the Fig. 9. The compass used for the measurement is accurate up to one degree. And the observed time from the dial was still in fair agreement with our watches within a minute. 
The grove along the meridian line is about $1 \mathrm{~cm}$ wide. The graduations on the dial all converge at the intersection of meridian line and the East-West line. It was difficult to make in situ measurements of the angular separation of the graduations with common tools. So, we used computer graphics to simulate the lines superimposed on a photograph of the dial taken carefully from a point just vertically above the center of the dial. The workmanship on the dial though, appears a bit crude, it is none the less a functional one.

Also, we worked out the theoretical calculations for the angular divisions graduated in time by 24 minutes, and notice that there is deviation of $.5^{\circ}-1.84^{\circ}$ between the theoretical and the observed values.

Theoretical calculations reveal that one graduation corresponding to shadow angle $78.70^{\circ}$ from the East-West line that is $11.30^{\circ}$ from the meridian line is missing on the dial. This discrepancy is found on both the sides of NorthSouth line.

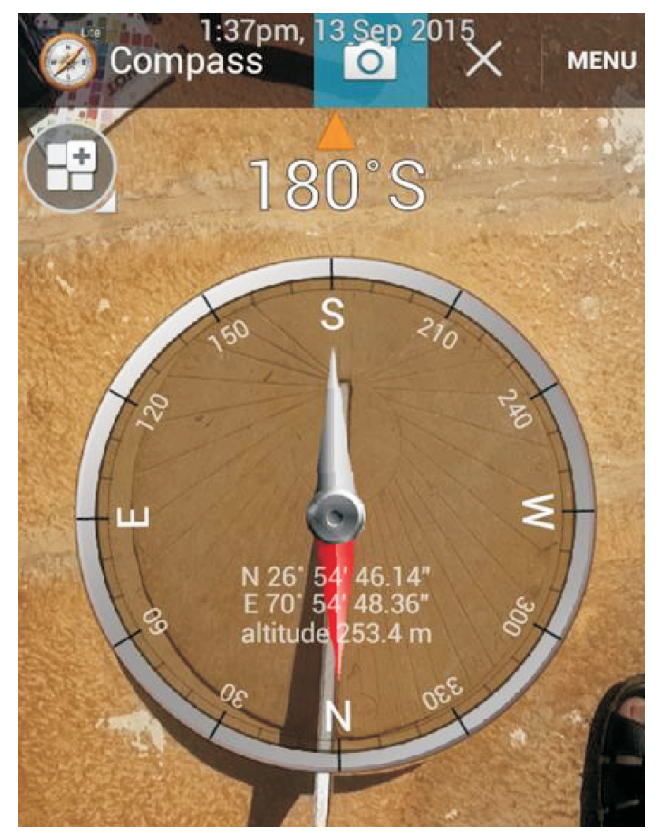

Fig. 9: Sundial recorded with a GPS application of a smart phone.
There is no structure or marking implying the positioning of the dial. With time, the limestone slab bearing the Sundial in Jaisalmer fort is getting deteriorated mainly due to weathering effects. These relics of the past need better upkeep and maintenance.

\section{ACKNowledgment}

The authors wish to express their gratitude to the Raj Mahal Palace Museum in the Jaisalmer fort and its staff for their cooperation during the study. The authors are grateful to Dr. Raghuveer Singh for lending books authored by him and sharing all available facts related to the History and the Sun and the weather dials. The authors also express their gratitude to local scholars Mr. Deen Dayal Ojha and Mr. Nand Kishor Sharma for their valuable help in reading the inscriptions and deliberations on historical aspects of the Sun-dial and the weather dial in the Jaisalmer fort.

\section{BibliograPHY}

Alfred, Gatty. The Book of Sun-Dials, George Bell and Sons, London (1872) pp. 1-2; http://digital.library.upenn. edu/women/gatty/sundials/sundials.html

Bose, D. M., Sen, S. N. and Subbarayappa, B. V. (ed.) $A$ Concise History of Science in India, Indian National Science Academy, 1971, pp. 72-135.

Das, M. R., Mukhopadhyay, R. K., Dandekar, M. M. and Kshirsagar, S. R. Pre-Monsoon Western Disturbances in Relation to Monsoon Rainfall, its' Advancement over Northwestern India and Their Trends, Current Science, 82 (11), 2002:1320-1321.

Forecasting Manual (Part-I). Surface Winds. 3.2.2, India Meteorological Department (1972) p.5;http://www.imdpune.gov.in/Weather/Forecasting Mannuals/IMD_I-2.pdf

Kaye, G. R. The Astronomical Observatories of Jai Singh, Archaeological Survey of India, New Imperial Series, Vol. XL, 1973.

Kochar, Rajesh and Narlikar, Jayant. Astronomy in India: Past, Present and Future, Inter University Centre for Astronomy and Astrophysics (IUCAA), Pune, and Indian Institute of Astrophysics, Bangalore, 1993, pp. 11-18. 
Kochar, Rajesh and Narlikar, Jayant. Astronomy in India, Indian National Science Academy 1994, pp. 6-9.

Rajasthan District Gazetteers- Jaisalmer, 1973, p. 27.

Raj Mahal Palace Museum and the Plaques of Archeological survey of India (ASI) in the Jaisalmer Fort.

Singh, Prahlad. Indian and Islamic Stone Observatories, Holiday Publications, Jaipur, 2009, pp 58-60.

Sharma, D. Rajasthan through the Ages- Vol. I, Rajasthan State Archives, 1966, p. 280.
Sharma, V. N. The Kapala Yantras of Sawai Jai Singh, IJHS 26.2 (1991):209-217.

Sharma, V. N. Jantar Mantar, Department of Art, Literature and Culture, Govt. of Rajasthan Published by Rupa and Co., 2008.

Shylaja, B. S. A Relook at the Observatory at Varanasi, Current Science, 100, No. 8 (2011) :1246-1249.

Tod, James. Annals and Antiquities of Rajasthan, Rupa Publications Pvt. Ltd. Reprint, 1997 New Delhi (First Published in London by Routledge and Kegan Paul Ltd. in 1832). 